Nidhomul Haq Vol 2 No: 3 November 2017

ISSN 2503-1481

\title{
ISLAM SEBAGAI PARADIGMA PENDIDIKAN MORAL UNIVERSAL
}

\author{
Rumina $^{1)}$ \\ Dosen Sekolah Tinggi Agama Islam Hasanuddin Pare Kediri \\ email: Kliknana79@gmail.com
}

\begin{abstract}
Islam mengatur kehidupan manusia sesuai dengan norma-norma Islam yang fundamental. Yaitu bahwa umat manusia dalam konsepsi ke Islaman mempunyai kewajiban yang sama dihadapan Tuhan tidak membedakan suku, bangsa, ras atau identitas yang lainnya. Maka dari itu Islam mempunyai pandangan yang sangat luas terhadap manusia, alam dengan menerapkan nilai spiritual dalam seluruh konsep kemanusiaan dan alam. Nilai-nilai pendidikan moral sangat penting artinya bagi kedamaian alam semesta. Itulah sebabnya konsep kenabian Muhammad diarahkan kepada suatu rahmat bagi alam semesta ini. Islam berpandangan bahwa manusia adalah makhluk Tuhan yang mendapat legalitas menjadi khalifah dibumi yaitu mengemban amanah untuk memakmurkan alam dan melestarikanya yang dikemas dalam kerangka "ibadah" kepada Allah. Dan konsep pendidikan moral universal dalam paradigma Islam adalah dalam kerangka mengembangkan kekhalifaan manusia yang mempunyai fungsi untuk menyelamatkan alam semesta dengan menghargai nilai-nilai kemanusiaan manusia. Pada era modern sesuatu yang sifatnya lokal, regional ataupun mungkin nasional bisa memudar, terutama yang berkaitan dengan hal-hal yang sifatnya moral. Pada era modern hegemini modernitas menjadi sangat kuat karena jiwa manusia yang miskin terhadap nilai-nilai. Pada saat itu manusia mempunyai sikap yang mendua (ambivalen). Dalam konteks ini pendidikan moral universal diperlukan untuk membina manusia agar bisa hidup dalam control nilai yang berlaku secara universal. Control yang sifatnya lokal maupun regional akan terhambat oleh hegemoni nilai-nilai modernitas. Oleh karena itu pendidikan moral universal yang tidak terpengaruh oleh hegemoni apapun harus bisa dikembangakan dalam era modrn. Sedangkan nilai pendidikan tidak ada yang bersifat universal selain dari Islam. Bagi umat Islam juga perlu mengembangkan pendidikan Islam ini, terutama dengan mengedepankan aspek nilai universal Islam. Nilai-nilai yang selama ini menjadi penghambat tumbuhnya persatuan dan kesatuan masyarakat, perlu segera dihilangkan. Sikap egaliter perlu semakin ditingkatkan, kesadaran hidup dalam perbedaan pandangan perlu dikembangkan pula. Sehingga dapat dikembangkan manusia yang lebih mengedepankan aspek humanism.
\end{abstract}

Keywords: Islam, Paradigma, Pendidikan Moral Universal

\section{PENDAhUluan}

Salah satu agama yang mendapatkan tanggapan terbesar dikalangan masyarakat Indonesia adalah Islam, tidak dialukan dengan cara kekerasan, melainkan dengan cara yang damai. Inilah yang diakui oleh para ahli sebagai suatu prestasi gemilang dari para ulama penyebar Islam. Dalam hal ini Ali dan effendi menyatakan ${ }^{1}$ :

\footnotetext{
${ }^{1}$ Aly, Fachri dan Effendy Bahtiar, Merambah Jalan Baru Islam, Mizan, (Bandung: Mizan, 1986), p. 28
}

\begin{abstract}
Keberhasilan Islam menembus dan mempengaruhi kehidupan masyarakat Indonesia serta menjadikan dirinya sebagai agama masyarakat Indonesia sebagai agama utama bangsa ini merupakan suatu prestasi luar biasa. Hal ini terutam dilihatbdari segi geografis, diamana jarak Indonesia dengan negar asal Islam, jazirah Arab, cukup jauh. Apalagi jika diingat bahwa, sejak dimulainya proses tersebarnya Islam waktu itu, sebagai gantinya, semata-mata mengandalkan kemampuan dan ketekunan tenaga da'i pedagang atau guru sufi.
\end{abstract}

Kenyataan sejarah memang demikian halnya, namun dari sudut lain perlu dipahami 
Nidhomul Haq Vol 2 No: 3 November 2017 ISSN 2503-1481

bahwa Islam merupakan suatu system yang konverhensive yang menyentuh dimensidimensi yang prural dan universal. Kontradiksi ajaran yang dibawa oleh Islam dengan ajaran Hindu waktu iyu juga mempunyai andil besar terhdap keberhasilan penyebaran Islam. Dalam kaitan ini terutama konsep amah (universal) ajarn Islam juga turut ambil bagian.

Konsep amah (universal) Islam ini ialah bahwaIslam bukan agama yang hanya diperuntukkan bagi bangsa Arab belaka. Selain itu, Islam juga bukan hanya mengatur sebagian dari sendi kehidupan kemanusiaan, melainkan mengatur seluruh sendi kehidupan kemanusiaan. Boisard dalam keteranganya yang panjang menyatakan ${ }^{2}$ :

Sebagai agama dan system social, universalisme Islam dapat dibuktikan dari empat segi. Yakni segi metafisik, segi agama, segi social dan segi politik. Empat segi tersebut diatas tidak akan menimbulkan konsep yang sangat berbeda, karena semuanya berasal dari satu sumber. Manusia dianggap sebagai merdeka dan bertanggung jawab, tetapi tidak terpencil karena ia adalah bersifat kolektif atau social dan akan mengalami suatu alam yang akhir.

Berdasarkan keterangan diatas, berarti Islam mengatur kehidupan manusia sesuai dengan norma-norma Islam yang fundamental. Pengertiannya bahwa umat manusia dalam konsepsi dipandang mempunyai suatu kewajiban yang sama tidak mempunyai perbedaan baik ras, suku bangsa, bahasa ataupun lainnya. Semua dipandang dalam kedudukan yang sama (egaliter) yang membedakan hanya nilai ketaqwaannya.

Oleh karena itu Islam mempunyai suatu pandangan yang sangat luas terhadap manusia, alam, dan yang terpenting lagi ialah nilai moral terhadap keduanya. Pada perinsipnya penulis berasumsi bahwa Islam mengajarkan nilai-nilai pendidikan moral universal.

Nilai- nilai pendidikan moral yang diajarkan oleh Islam itu sangat penting artinya bagi kedamaian alam semesta. Itulah

2 Boisard, Marcel A. L'Humanisme DeL'Islam, alih bahasa M. Rasjidi, (Jakarta: Bulan Bintang, 1980), p. 184 sebabnaya konsep kenabian Muhammad diarahkan sebagai suatu rahmat bagi alam semesta ini. Berdasarkan pemikiran-pemikiran diatas maka penulis terinspirasi untuk mengkaji tentang nilai-nilai Islam universal dengan mengangkat judul "Islam Sebagai Paradigma Pendidikan Moral Universal"

\section{ISLAM DAN KANDUNGAN AJARANYA}

\section{a. Hakekat Islam}

Untuk membahas Islam dan seluruh aspek-aspeknya yang universal, terlebih dahulu perlu dijelaskan tentang hakekat agama itu sendiri.

Menurut Abdalati "kata Islam berasal dari bahasa Arab 'SLM' (Sin, Lam, Mim) artinya antara lain: damai, suci, patuh dan taat (tidak pernah membantah)"'s. Keterangan ini sama dengan keterangan yang disampaikan oleh Tatapangarsa bahwa Islam, ditinjau dari sudut bahasa mengandung beberapa arti, yakni:

1. Menyerahkan diri, yakni menyerahkan diri kepada kehendak Tuhan. Maka seorang muslim ialah orang yang telah menyerahkan dirinya kepada Tuhan, tunduk kepada perintah-perintah dan larangan-larangan-Nya, atau kepada ketentuan apapun yang telah ditetapkan oleh-Nya.

2. Damai, yakni damai dengan sesama manusia. Jadi Islam ialah agama yang membawa ajaran perdamian bagi umat manusia.

3. Selamat. Yakni selamat dunia akhirat. Siapapun akan selamat sejahtra dunia akhiratnya, apabila menganut Islam dan menaati ajaran-ajaranya ${ }^{4}$.

Arti kata Islam sebagaimana disebutkan diatas sekaligus menunjukan karakter Islam sebagai agama dan konsep moral universal. Dalam kaitan ini Isngadi menjelaskan:

3 Abdalati, Hammudah, Islam Suatu Kepastian, (Riyadh: Natinal Offset Printing Press, 1986) p. 13

${ }^{4}$ Tatapangarsa, Humaidi,1982, Kuliah Aqidah Lengkap, (Surabaya: Bina Ilmu, 1982), p. 29 
Nidhomul Haq Vol 2 No: 3 November 2017 ISSN 2503-1481

....Islam itu suatu agama yang mempunyai cirri universal, umum dan mengandung makna sesuai dengan pembawaan (fitrah) asli manusia yang bercita-citakan hidup "selamat, sejahtra, aman dan bahagia" itulah arti Islam. Seluruh kehidupan di ala mini memiliki sifat "Aslama" (penyerahan diri secara mutlak menurut hukumalam baik terpaksa maupun sadar). ${ }^{5}$

Kesimpulan bahwa Islam adalah agama universal kiranya tidak berlebihan, sebab Islam memang ditunjukan untuk kehidupan manusia global bahkan alam semesta. Disinilah makna firman Allah yang menegaskan bahwa Islam diturunkan sebagai rahmat bagi alam secara keseluruhan, sebagai rahmat bagi alam secara keseluruhan, sebagaimana firman-Nya (Depag RI,1986/1987:508)

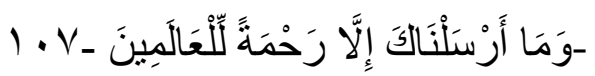

"Dan tiadalah kami mengutus kamu, melainkan untuk (menjadi) rhmat bagi semesta alam”. (QS.Al-Anbiyaa: 107).

Dengan demikian pengertian dan hakekat Islam adalah sebagai berikut:

1. Agama (ajaran) yang dibawa oleh Nabi Muhammad saw. Yang mengajarkan tentang nilai-nilai moral (sikap menyerah) universal.

2. Agama yang mengajarkan tentang ketaatan terhadap nilai-nilai keimanan (syahadatain) yang diwajibkan berdasarkan ketentuan syariah Islam.

3. Nilai universal ajaran Islam menyentuh dimensi global bahkan sebagai rahmat bagi alam semesta.

\section{b. Dasar-Dasar Hukum Islam}

Membahas tentang dasar-dasar hokum Islam tentu menarik sekali, sebab Islam diturunkan oleh Allah tudak untuk mengekang manusia, melainkan merangsang bagi manusia agar bisa lebih mengembangkan potensi

5 Isngadi, 1997, "Kearah pengertian Islam", Mimbar Pembangunan Agama, p. 31 fitrahnya menuju kepada hidayah Islam. Oleh kerena itulah Islam turun dengan satu system dan term kemanusiaan yang universal dengan dasar-dasar universalism yang mengacu kepada sumber-sumber hukum Islam.

Membahasa hal yang berkaitan dengan dasar-dasar Islam, Rosulullah saw telah menggariskan pada sabdahnya dalam riwayat Baihaqi, sebagai berikut:

$$
\begin{aligned}
& \text { تر كت فيكم شيئين لن تضلو ا بعد هما....... } \\
& \text { كتاب الله وسنتي ولن يتفرقا............ }
\end{aligned}
$$
keduanya tidak akan menyesatkan bagimu yaitu kitab Allah (Al-qur'an) dan sunnahku dan janganlah kamu terpecah....."(HR Baihaqi)

Berdasarkan pada sabdah nabi diatas bisa diambil pengertian bahwa Islam telah menentukan dasar-dasar yang universal yaitu kitab Al-qr'an dan sunnnah Nabi. Akan tetapi Karena Al-qur'an dan al-sunnah banyak yang mengandung makna ijtihad akhirlah berkembanglah pandangan bahwa sumber hokum Islam itu ada empay yaitu ijma' dan qiyas, selain Al-qur'an dan al-sunnah itu sendiri, dua tambahan tersebut termasuk ra'yu (logika).

1). Al-Qur'an sebagai dasar utama hukum Islam

Al-Qur'an sebagai dasar pertama Islam memuat konsep-konsep ajaran Islam secara global (ijmaly) kandungan Al-Qur'an memuat beberapa unsure diantaranya adalah:

a) Aqidah yang mewajibkan beriman kepada Allah, Malaikat, kitab-kitab Rasul-rasul dan hari akhirat, ini merupakan garis pemisah antara iman dan kafir.

b) Ibadah, sebagai perbuatan yang menghidupkan aqidah dalam hati.

c) Janji dan ancaman.

d) Jalan-jalan mencapai kedunia maupun akhirat. Peraturan dan hukum-hukum tersebut ada yang mengatur manusia dengan Allah (vertikal) dan hubungan antara sesame umat manusia (horizontal) 
Nidhomul Haq Vol 2 No: 3 November 2017 ISSN 2503-1481

e) Riwayat dan cerita ${ }^{6}$

Dengan demikian al-qur'an cukup lengkap sebagaisumber referensi kehidupan manusia. Namun demikian, karena Al-Qur'an mengemukakan konsep dasarnya saja, maka di perlukan sumber lain yaitu al-sunnah (hadits) sebagai penjejas (bayan).

2). Al-Sunnah srbagai dasar kedua Islam

Banyak pengertian tentang al-sunnah dikembangkan oleh para ahli, hanya saja menurut Murtadho definisi al-sunnah yang dikemukakan ahli hadits lebih luas, yaitu meliputi segala "yang datang dari Nabi baik berupa ucapan, perbuatan, ketetapan, perjalanan hidup hidup dan lain-lainnya, yang berupa hukum atau tidak, yang dilakukan sebelum menjadi Rosul atau sesudahnya" (Murtadho,1989:8). Dalam hal ini penulis mengadopsi pandangan ini adalah bahwa seluruh yang dating dari Nabi adalah sesuatu al-sunnah yang dijadikan teladan bagi umat Islam. Pandangan ini didasarkan pada kenyataan bahwa Nabi Muhammad adalah teladan umat manusia (uswah hasanah).

Kehujjahan al-sunnah telah diterima oleh kalangan umat Islam, dengan tidak ragu lagi al-sunnah Nabi yang shahih sama halnya kedudukannya dengan al-qur'an. Dengan demikian al-sunnah atau al-hadits, yakni sebagai sumber hukum Islam setelah al-quran dalam pengertian bahwa kehujjahan al-sunnah dapat diterima.

Sumber lain yang seringkali dibahas adalah ra'yu yang meliputi banyak jenis, diantaranya ijma', qiyas, al-istishab, dan sebagainya. Pada bagian ini penulis hanya akan membahasa dua saja, ialah ijma' dan qiyas sebagai sumber yang seringkali dibahasa dikalangan ulama.

\section{3) Ijma' Ulama/Mujtahidin}

Ijma' ini tidak ada pada masa Nabi, namun ijma' berjalan sejak masa sahabat sampai pada masa sekarang ini. Ijma' ini merupakan kesepakatan, baik kesepakatan

\footnotetext{
${ }^{6}$ Syauki, Achmad,1993, Lintasan Sejarah AlQur'an, (Bandung: Sulita, 1993) p. 14
}

para sahabat, tabi'in ataupun ulama mujtahid dan sebagainya. Logika kehujahan ijma' ini dikemukakan dalam Dirasat Islamiyyah ketika menjelaskan ayat 77 dari surah An-Nisa' (Depag RI,1986/1987:131) yaitu:

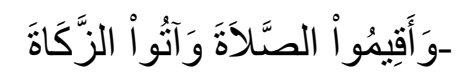

“......dirikanlah sembahyang dan tunaikanlah zakat......” (Qs. An-Nisa':77)

Dalam ayat tersebut tidak dijelaskan secara rinci tentang bagaimana mendirikan sholat dan menunaikan zakat, kemudian Rosulullah menjelaskan kegelobalan ayat tersebut dengan sunnah qauliyah dan sunnah fi'liyah. Kalau seandainya sunnah yang menjelaskan itu bukan hujah atas umat Islam, maka sudah barang tentu tidak akan dapat meleksanakan fardhu yang ditetapkan alqur'an atau mengikuti hukum-hukumnya (Tim Penyusun,1995:36)

Dengan demikian ijma' sebagai dasar hukum Islam bisa diterima, namun muara nilainya harus kepada al-quran yang derajat kualitasnya qath'i. ijma' tidak boleh bertentangan dengan sumber hukum yang lebih tinggi baik itu al-quran maupun alsunnah.

\section{4). Qiyas}

Qiyas merupakan bagian dari sember hukum Islam yang pengertiannya adalah upaya penalaran analogis yang membuka jalan untuk mengembalikan atau mengkaitkan sesuatu far' (suku/bagian masalah) atau berdasarkan materi hukum yang autentik (manthuq/manshush) atau berdasarkan materi hukum yang padanya sudah ada kesepakatan (mujma'alaih) ${ }^{7}$.

Qiyas sebagaimana ijma' merupaka bagian dari ra'yu yang produk hukumya tidak boleh bertentangan dengan Al-qur'an dan AlSunnah.

${ }^{7}$ Yafie, Ali "Menggagas Fiqih dan Pranata Sosial, dalam muntaha Azhari (Eds), Islam Indonesia Menatap Masa Depan, (Jakarta: P3M, 1989), p. 43 
Nidhomul Haq Vol 2 No: 3 November 2017 ISSN 2503-1481

Keempat dasar diatas dua yang pertama merupakan dasar Islam yang pokok sedangkan dua yang kedua merupakn cabangnya saja. Boleh dikata bahwa dua yang belakang merupakan system penggalian hukum dari sumber yang utama di atas. Oleh karena itu status dasar Islam tersebut juga berbeda, sebagaimana di jelaskan sebgai berikut:

Keempat sumber hukum Islam yang disepakati itu oleh Musthafa Az-Zarqa' dua diantaranya digolongkan sebagai almashadirbal-asasiyyah (sumber hukum primer) yaitu al-qur'an dan sunnah, sedangkan yang lain dikelompokan al-mashadir attaba'iyahn (sumber skunder) hal itu dikarenakan ijma' dan qiyas masih diperselisihkan sebagai sumber hukum melainkan sebagai alat penggali hukum (Tim penyusun, 1995:63).

Berdasarkan uraian diatas dapat diambil kesimpulan bahwa sumber hukum Islam menyangkut dua hal yaitu sumber dari nash yang meliputi nash Al-Qur'an dan nash al-sunnah serta ra'yu.

\section{ISLAM DAN PANDANGAN PENDIDIKAN MORAL UNIVERSAL}

\section{a. Pendidikan Moral}

Secara etimologis Pendidikan berarti "proses pengubahan sikap dan tata laku seseorang atau kelompok orang dalam usaha mendewasakan manusia melalui pengajaran dan latihan" Moral berarti "(ajaran) baik buruk yang diterima umum mengenai perbuatan, sikap, kewajiban....", sedangkan pengertian universal adalah "umum (berlaku untuk semua orang atau untuk seluruh dunia)"

Dari uraian diatas dapat diambil pengertian bahwa yang dimaksud dengan pendidikan moral universal adalah nilai pengubahan sikap dan tata laku yang bersifat umum dan berlaku pada seluruh umat manusia didunia,

${ }^{8}$ Moeliono, Anton M., et,al, , Kamus Besar Bahasa Indonesia, (Jakarta: Balai Pustaka, 1989) 992
Pendidikan moral universal perlu dijabarkan dalam bentuk paradigm yang transparan, dengan tujuan mengedepankan aspek nilai yang dikandung oleh ajaran moral universal. Dalam konteks ini penulis berpandangan bahwa moral universal itu terangkum dalam ajaran Islam, maka pembahasan ini pun tidak terlepas dari konsep Islam. Islam adalah agama yang setidaknya mengkonsepkan prinsip-prins sebagai berikuti:

a. Allah adalah pencipta dan sumber dari segala kebaikan, kebenaran dan keindahan.

b. Manusia adalah makhluk yang diberi tanggung jawab, sebagai kholifah yang penuh kemuliaan dan keagungan dari penciptanya.

c. Allah telah menjadikan yang ada dilangit dan dibumi hanyalah untuk mencukupi kebutuhan manusia.

d. Denagan kasih sanyang dan kebijakkanNya, Allah tidak akan menyuruh manusia melakukan apa-apa yang tidak mungkin dilakukannya, dan sebaliknya Allah tidak melarang manusia untuk menikmati hidup ini.

e. Sikap luwes/lunak praktis dan seimbang merupakan jaminan yang tinggi bagi ketulusan hati dan moral.

f. Segala sesuatu pada prinsipnya boleh dikerjakan, dengan berpegang pada ketentuanyang wajib harus dikerjakan dan yang dilarang harus ditinggalkan,

g. Manusia dituntut untuk bertanggung jawab kepada Allah dan tujuannya yang paling tinggi adalah keridhaan-Nya. ${ }^{9}$

Berdasarkan uraian diatas dapat diambil kesimpulan bahwa pendidikan moral universal yang dimaksud pada pembahasan ini adalah moral universal yang bersandar kepada nilainilai universal ajaran Tuhan yang memiliki jangkauan pada semua makhluk berupa alam semesta denga isinya. Kecenderungan moral universal yang dimaksud adalah pada nilainilai akhlak.

9 Abdalati, Hammudah, Islam Suatu Kepastian, 88 
Nidhomul Haq Vol 2 No: 3 November 2017 ISSN 2503-1481

\section{b. Nilai-nilai Moral Universal Ajaran Islam}

Nilai moral dalam Islam bermacammacam, jangkauannya sangat jauh dan lengkap. Moral Islam tergantung pada hubungan dengan Allah, manusia dengan manusia lainya, manusia dengan elementelemen lain dari semua makhluk di alam semesta dan antara manusia dengan dirinya sendiri. Manusia harus menjaga tabiat kelakuannya dan tindakan-tindakannya, ucapan dan pemikirannya, perasaan dan perhatiannya.

Ketakwaan terhadap Tuhan merupakan dimensi pertama nilai ajaran Islam, dalam hal ini Madjid (1992:40) menjelaskan ${ }^{10}$ :

Mengikuti tema-tema al-qur'an sendiri, penanaman rasa takwa kepada Allah sebagai dimensi pertama hidup ini dimulai dengan pelaksanaan kewajiban-kewajiban formal agama berupa ibadat-ibadat. Dan pelaksanan itu harus disertai dengan penghayatan yang sedalam-dalamnya akan makna ibadat-ibadat tersebut, sehingga ibadat-ibadat itu tidak dikerjakan semata-mata sebagai ritus (upacara) formal belaka, melainkan dengan keinsafan mendalam akan fungsi edukatifnya bagi kita. Dengan cara inilah antara lain kita dapat selamat dari ketakutan Tuhan atasa tindakan beribadat yang muspra (sia-sia).

Nilai-nilai moral Islam yang bisa dikembangkan yang berkaitan dengan dimensi ini diantara, silahturahim, persaudaraan (ukhuwwah), persamaan derajat (egalitarian al-musawwah), adil (adl), baik sangkah (husnu dzan), rendah hati (tawadu'), tepat janji (alwafa), lapang dada (al-insyirah), dermawan (al-munfiqun) dan sebagainya

Dengan demikian bahwa nilai-nilai moral ajaran Islam adalah nilai-nilai moral yang bersumberkan kepada nilai ketuhanan (taqwa) dan nilai kemanusiaan.

10 Madjid, Nurcholish, Islam Keindonesiaan dan Kemodernan, (Bandung: Mizan, 1992) 47-48

\section{c. Potensi dan Tanggung Jawab Manusia}

Sebelum mengemukakan secara panjang lebar tetang pandangan Islam terhadap manusia, terlebih dahulu perlu dikemukakan kisah diciptakanya manusia dal Al-qur'an pada surah Al-Baqarah ayat 30:

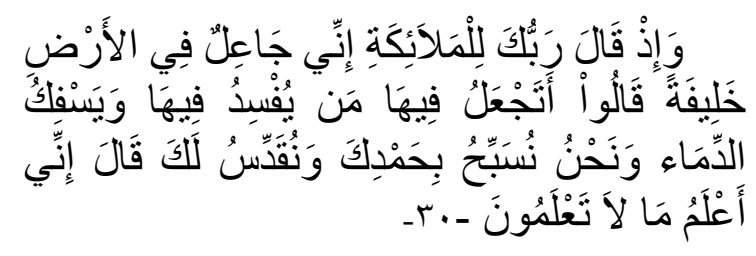

"Ingatlah ketika Tuhanmu berfirman kepada para Malaikat "sesungguhnya Aku hendak menjadikan seseorang khalifah di muka bumi" Mereka berkata: "mengapa engkau hendak menjadikan (khalifah) di bumi itu orang yang akan membuat kerusakan padanya dan menumpahkan darah, padahal kami senantiasa bertasbih dengan memuji Engkau dan mensucikan Engkau?". Tuhan berfirman:" sesungguhnya Aku mengetahui apa yang tidak kamu ketahui" (Depag RI,1986/1987;13).

Ayat diatas menegaskan secara eksplisit tentang pandangan Islam terhadap manusia adalah makhluk istimewa yang di beri tugas untuk mengelolah bumi dalam konsep "kehalifahan" khalifah ini adalah tugas utama atau tugas induk manusia, sedangkan tugastugas lain merupakan aplikasi dari kehalifahan ini.

Manusia yang diberi tugas sebagai khalifah oleh Allah diberi potensi-potensi tertentu untuk pengembangan dirinya. Potensipotensi tersebut merupakan alat pendukung bagi kedudukannya sebagai khalifah di bumi (khalifahtu fi al-ardh). Sasona mengemukakan. ${ }^{11}$

Dalam Islam, fitrah manusia adalah menjadi pelaku pokok atau subyek, bukan penderita atau obyek. Panggilan manusia sejati

11 Aly, Fachri dan Effendy Bahtiar, Merambah Jalan Baru. 218 
Nidhomul Haq Vol 2 No: 3 November 2017 ISSN 2503-1481

adalah menjadi pelaku yang sadar, yang berindak mengatasi dunia dan realitas yang menindas. Dunia dan realitas dunia itu, bukanlah sesuatu yang ada dengan sendirinya, dank arena itu harus diterima menurut apa adanya sebagai suatu takdir dan semacam nasib yang tak terelakkan. Seseorang yang mabusiawi, harus menjadi pencipta sejarahnya sendiri. Dan karena sesorang hidup di dunia bersama orang lain sebagai umat manusia, maka kenyataan ada bersam itu harus dijalani dalam proses "menjadi" yang tak pernah selesai. Ini bukan sekedar adaptasi, tapi integrasi untuk menadi manusia seutuhnya.

Berdasarka uraian diatas dapat diketahui bahwa manusia dalam kemerdekaannya sebagaimkhalifah mempunyai tugas sebagai pemakmur bumi dan sekaligus bertanggung jawab terhadap semua perbuatannya sendiri

\section{d. Hubungan Islam dengan Pendidikan Moral Universal}

Membicarakan prihal hubungan Islam dengan moral universal sebenarnya ibarat membicarakan diri sendiri. Sebab Islam pada dasarnya adalah juga pendidikan moral universal itu sendiri. Kenyataan ini tidak bisa dibantah karena Islam sebagai agama samawi memang diperuntukkan bagi pendidian makhluk yang ada di bumi ini tidak dengan membedakan suku, bangsa, bahasa ataupun lainnya. Betapa penting peran Islam dalam konteks pendidikan moral universal, mengemukakan ${ }^{12}$ :

Jika agama benar-benar merupakan sesuatu yang vital, tidak hanya bagi perseorangan, tapi juga untuk masyarakat, maka ia dituntut untuk memiliki tiga hal: ia harus merupakan way of life yang dapat dirasakan secara mendalam oleh pribadi- apa yang hendak dilakukan oleh seseorang dalam kesendiriannya- kata Whitehead, sebagai suatu way of life bersama yang didasarkan pada pendekatan spiritual dan emosional tertentu, kepercayaan-kepercayaan tertentu, pedomanpedoman tertentu dalam bidang nilai, dan sikap-sikap tertentu dalam menghadapi nasib manusia. Dan sebagaimana sekarang ini pun

\footnotetext{
12 Madjid, Nurcholish, Islam Keindonesiaan.
}

telah ada masyarakat-masyarakat agama atau jama'ah-jama'ah, maka demikian pula, agama dimasa mendatang memerlukan organisasi sendiri sebagai rangkanya. Dan akhirnya dan inilah yang sering hilang di masa lalu akibat pertentangan antara dasar pemikiran religious dan ilmiah, masyarakat agama dan kehidupan individual orang-orang agama harus mempunyai suatu hubungan organis dengan masyarakat secara keseluruhan dalam hal yang berkenaan dengan pikiran, moral dan perasaan. Hal itu berarti bahwa keagamaan harus relevan dengan kehidupan nyata. hubungannya dengan hal ini, maka kita sering lupa bahwa dunia ini sebenarnya senantiasa berkembang. Sedangkan dalam setiap perkembangan, tentu berarti terdapat perubahan. Maka keagamaan harus mampu menampung perubahan masyarakat (social change).

Konsep yang dikemukakan oleh madjid diatas mengedepankan aspek universal Islam yang bisa untuk segala zaman dan keadaan. Pada dasarnya memang demikian halnya, Islam tidak mengenal tentang waktu, nilai universal Islam berlaku bagi segala zaman dan kondisi apapun termasuk juga kepada siapapun.

Islam mempunyai hubungan yang kontributif sifatnya terhadap pendidikan moral universal. Pengertiannya bahwa ajaran Islam merupakan ajaran yang mengedepankan aspek moral. Ajaran moral Islam bersifat global dan universal yang berfungsi bagi segala kelompok, suku, ras, bangsa.

\section{e. Fungsi Pendidikan Moral Universal}

Pendidikan identik dengan pengembangan moral, maka pengembangan moral itupun pada dasarnya adalah untuk tujuan sebagaimana tujuan pendidikan internasional. Disini terletak fungsi pendidikan moral universal yaitu untuk mengembangkan nilai-nilai yang berfungsi secara universal untuk mewujudkan kesejahtraan manusia dan alam semesta. Dalam konteks ini moral universal secara oprasional berfungsi untuk "memperkuat hubungan antar anggota masyarakat, mempersatukan perasaan yang merupakan dasar kebajikan universal dan mempersatukan 
Nidhomul Haq Vol 2 No: 3 November 2017 ISSN 2503-1481

kaidah-kaidah yang memaksa yang sangat perlu bagi kehidupan kolektif". ${ }^{13}$

Dari sini dapat dipertegas bahwa pendidikan moral universal ini berfungsi untuk mengikat hubungan manusia secara kolektif dan menyuruh sifatnya.

\section{KONSEP PENDIDIKAN ISLAM TENTANG PENDIDIKAN MORAL UNIVERSAL DALAM TINJAUAN ANALISIS}

\section{a. Manusia dan Pendidikan}

Ahli pendidikan Islam sepakat bahwa manusia lahir dalam keadaan fitrah, dan fitrah ini harus dikembangkan agar manusia bisa hidup sesuai dengan fitrah yang dibawanya sejak lahir, seperti dalam al-qur'an surat ArRuum : 30 yaitu:

Maka hadapkanlah wajahmu dengan lurus kepada agama (Allah), (tetap atas) fitrah Allah yang telah menciptakan manusia menurut fitrah itu. Tidak ada perubahan pada fitrah Allah. (itulah) agama yang lurus; tetapi kebanyakan manusia tidak mengetahui (Depag RI,1986/1987:645).

Adanya fitrah yang berpotensi positif pada diri manusia ini, merupakan suatu tanda yang jelas bahwa manusia adalah makhluk yang bisa diarahkan, dibina maupun dididik bahkan potensi fitrah ini menunjukan bahwa manusia itu adalah makhluk yang harus didik. Pengembangan fitrah manusia ini harus dilakukan dengan pendidikan Islam. Tidak ada institusi yang mampu membina fitrah manusia kecuali pendidikan Islam. Maka, pendidikan Islam dalam konteks ini diarahkan atau ditunjukan untuk mengembangkan potensi fitrah manusia agar memepunya nilai produktif dan kreatif serta positif.

\section{b. Alam Manusia}

\section{1) Tugas Manusia}

Tugas manusia dimuka bumi ini adalah untuk menjadi khalifah di bumi (khalifalu $f i$ al-ardh), maka tugas manusia adalah menjaga bumi dengan cara

13 Boisard, Marcel A. L'Humanisme DeL'Islam, 184

memakmurkannya. Konsepsi khalifah pada manusia ini sebenarnya memberikan kedudukan yang lebih tinggi pada derajat manusia, sekaligus juga menunjukan bahwa manusia merupakan makhluk yang harus bertanggung jawab. Allah berfirman dalam surah adz-Dzariyaat ayat 56 sebagai berikut:

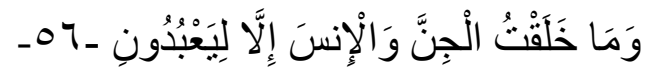

Dan Aku tidak menciptakan jin dan manusia melainkan supaya mereka menyembah-Ku (Depag RI,1986/1987:862)

Berdasarkan firman Allah di atas ada tugas utama bagi manusia terhadap bumi ini setidaknya mengandung tiga unsure yaitu:

a. Ikatan manusia dengan Tuhannya melalui jalan penjagaan dan ketundukan.

b. Pendidikan akhlak manusia, mengingatkan kewajibannya terhadap dirinya dan manusia lain, menguatkan ikatan kasih saying dan tolong menolong antara dirinya dan manusia-manusia lain.

c. Menangkaskan jasmani manusia, menguatkan anggota badannya, melatih untuk menanggung hal-hal yang sulit, dahaga dan kesempitan hidup.

Dengan demikian, manusia sebagai khalifah di bumi mempunyai kewajiban eksistensi dirinya kepada Tuhan dengan cara menjaga kelestarian bumi dan isinya, mengembangkan suasana damai dalam kehidupan di bumi, serta mengembangkan nilai-nilai pengembangan bagi kelestarian bumi.

\section{2) Kerusakan di Bumi}

Kenyataan bahwa manusia merupakan perusak alam memang sudah menjadi catatan sejarah kehidupan manusia. Pertumbuhan dan perkembangan industry banyak menimbulkan kerusakan, dan perang pun juga demikian halnya. Oleh sebab itu, agar lingkungan alam semesta ini bisa diselamatkan dari tangantangan manusia yang merusak perlu 
Nidhomul Haq Vol 2 No: 3 November 2017 ISSN 2503-1481

ditumbuhkan suatu kebijakan untuk mempertahankan lingkungan alam dengan mengedepankan sasaran:

a. Membina hubungan keselarasan antara manusia dengan lingkungan. Ini merupakan bagian dari tujuan pembangunan untuk membina manusia Indonesia seutuhnya yang memiliki cirri-ciri keselarasan: a). antara manusia dengan masyarakat, b). antara manusia dengan lingkungan, dan c). antara manusia dengan Tuhan penciptanya.

b. Melestarikan sumber-sumber alam, agar dapat dimanfaatkan terus menerus oleh generasi demi generasi.

c. Mencegah kemerosotan mutu lingkungan, dan meningkatkannya sehingga dapat menaikan kualitas hidup manusia Indonesia. Pembangunan industry, pertambangan, pertanian dan kegiatan sektiral lainnya dilaksanakan melalui cara yang mengindahkan mutu lingkungan.

d. Membimbing manusia dari posisi "perusak lingkungan" menjadi "pembina lingkungan"14.

\section{c. Pendidikan Moral Universal dalam Era Modern}

Nilai-nilai lokal tidak akan mampu menghadapi nilai-nilai yang dibawa oleh modernisasi. Sejarah menunjkan bahwa nilainilai lokal yang berbentuk suatu tradisi ataupun budaya tidak mampu menahan gejolak modernisasi ini. Ini merupakan kenyataan yang tidak dapat dipungkiri bahwa nilai-nilai modernitas akan mengkikis nilai-nilai budaya bahkan moral, masyarakat industrial merupakan gambaran bukti nyata bahwa masyarakat tradisional mudah terpengaruh oleh sesuatu yang baru, yang dimitoskan sebagai modern.

Perkembangan ilmu penegetahuan dan teknologi akan mewarnai pola hidup

\footnotetext{
14 Hasan Muhammad Thalchah, 1988, ”Aspek Manusia dalam Upaya pelestarian Lingkungan",Aula Risalah Nadhatul Ulama Jawa Timur, No.3/Maret. 58-59
}

masyarakat modern, yaitu pola hidup yang rasional dan materialism maka nilai-nilai yang dianggap skral cenderung akan memudar. Dalam konteks yang seemikian menurut madjid" 15 "dari sudut pandang Islam, hanya segi metode dan empirisme ilmu ilmu pengetahuan modernlah yang nampaknya abash (valid). Sedangkan dalam hal moral dan etika, ilmu pengetahuan modrn amat miskin. Hal ini bisa menjadi sumber ancaman lebih lanjut umat Islam”.

Disinilah diperlukan pendidikan moral universal, ialah pendidikan moral yang mengarahkan pola hidup manusia dalam kerangka yang manusiawi, humanis dan moralis. Pertanyaan yang muncul adalah mengapa moral universal?

Pada era modern sesuatu yang sifatnya lokal, regional ataupun mungkin nasional bisa memudar, terutama yang berkaitan dengan halhal yang sifatnya moral. Pada era modern hegemini modernitas menjadi sangat kuat karena jiwa manusia yang miskin terhdap nilai-nilai. Pada saat itu manusia mempunyai sikap yang mendua (ambivalen) sebagaimana dikemukaan sebagai berikut ${ }^{16}$ :

Menghadapi kemajuan iptek yang demikian itu, sikap manusia ternyata membelah dan bercabang, untuk kemudian terkesan menjadi mendua alias ambivalen. Disatu pihak senanglah manusia memperoleh kemudahan-kemudahan hidup yang tak layak lagi- dikatan secara umum- telah mempertinggi kwalitas yang fisik. Namun dilain pihak keraslah pula keluh kesah manusia ini karena keterpaksaannya untuk mengadaptasikan diri kesituasi baru yang tak layak lagi terasa human ceantric melainkan amat technocentric. Dalam perubahan yang

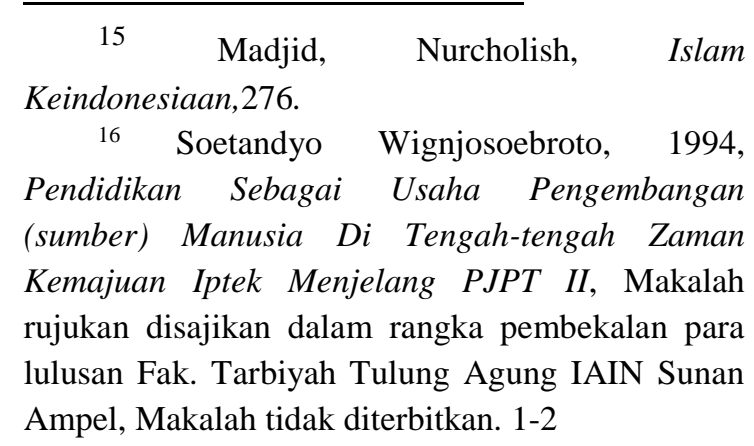


kian amat technocentric seperti itu manusia dalam jumlahnya yang masalah tak lagi dikontrol secara otonom oleh nurani pribadinya atau kaidah-kaidah sosialnya sendiri yang otonom dan lokal, melainkan oleh kekuatan eksternal yang sentral.

Dalam konteks ini pendidikan moral universal diperlukan untuk membina manusia agar bisa hidup dalam control nilai yang berlaku secara universal. Control yang sifatnya lokal maupun regional akan terhambat oleh hegemoni nilai-nilai modernitas.

Oleh karena itu pendidikan moral universal yang tidak terpengaruh oleh hegemoni apapun harus bisa dikembangakan dalam era modrn. Sedangkan nilai pendidikan tidak ada yang bersifat universal selain dari Islam. Dalam konteks ini selain nilai universal Islam bisa dilihat dari konsep khalifah dalam Al-Qur'an Al-Baqarah ayat 30

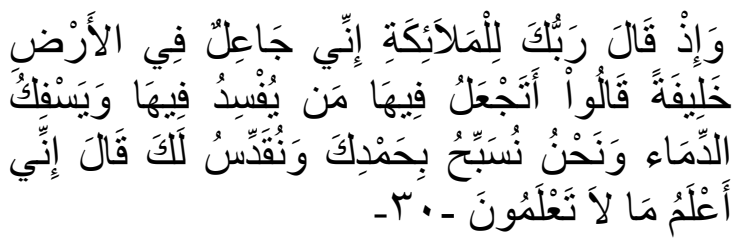

Ingatlah ketika Tuhanmu beriman kepada para malaikat "sesungguhnya Aku hendak menjadikan seseorang khalifah di muka bumi". Mereka berkata: "mengapa Engkau hendak menjadikan khalifah di bumi itu orang yang akan membuat kerusakan padanya dan menumpahkan darah, padahal kami senantiasa bertasbih dengan memuji Engkau dan mensucikan Engkau" Tuhan berfirman: "sesungguhnya Aku mengetahui apa yang tidak kamu ketahui”. (Depag RI ,1986/1987:13).

Konsepsi tentang khalifah dalam Islam bersifat universal. Khalifah dalam konteks ayat tersebut diatas tidak berarti parsial, melainkan berarti amm dan universal. Disisni petunjuk jelas bahwa nilai-nilai Islam itu bersifat universal, karena moral Islam merupakan pengawal kemakmuran dan kesejahtraan idi bumi atau alam semesta ini.

\section{d. Islam dan Pendidikan Moral Universal}

Saifullah mengemukakan sejarah manusia sebagai "suatu sejarah perang, sehingga peristiwa perdamaian adalah tiada lain dari persiapan perang berikutnya. Maka kita harus berusaha mempertahankan perdamaian dan membina perdamaian". Dalam gagasannya saifullah mengemukakan bahwa perdamaian itu dilaksanakan dengan media pendidikan internasional.

Tujuan pendidikan iternasional yang dimaksud adalah untuk "membina perdamaian dunia, yang berdasar atas kebebasan, keadailan dan persaudaraan, sehingga terbina bangsa dan dunia yang sejahtra, spiritual dan materiil" ${ }^{17}$.

Gagasan pendidikan internasional saifullah tersebut bagi Islam bukan sesuatu yang baru, sebab sebelum dikemukakan hal itu, Islam telah memiliki suatu konsep pendidikan internasional dan bahkan moral universal. Hal ini dapat dilihat dari dasar-dasar pembentukan masyarakat Islam pada saat Rosulullah saw. Mengadakan perjanjian dengan orang-orang yahudi, yang konsepnya dikenal dengan piagam madinah.

Piagam madinah merupakan pijakan bagi nilai-nilai Islam terutama berkaitan dengan hubungan kemanusiaan secara universal. Piagam madinah ini memberikan dasar-dasar utama hubungan internasional, hubungan global, atau hubungan universal yang dilandasi oleh nilai-nilai universal pula. Piagam madinah tersebut merupakan pijakan utama pembentukan masyarakat dunia yang demokratis dan merupakan dasar-dasar pemikiran modern yang demokratis. Nilai yang tercakup pada piagam itu setidaknya mengandung tiga hal yaitu tentang kebebasan beragama, nasionalisme dan hukum tatanegara (justicia).

alam konteks lain piagam madinah mengedepankan aspek hukum dalam kehidupan manusia. Aspek hukum ini penting sekali untuk menegakan kebajikan, sebab

17 Saifullah, Ali, Pendidikan Internasional and edult Education, (Surabaya: Usaha Nasional, 1983) p. 21 
Nidhomul Haq Vol 2 No: 3 November 2017 ISSN 2503-1481

masyarakat tanpa hukum akan jatuh, aoleh karena tindakan melanggar hukum akan mengikis nilai-nilai yang dipegang masyarakat. Disini demokrasi yang diangkat oleh Islam diatur dalam batas hukum-hukum tertentu, untuk mengawal masyarakat mencapai tujuan yang dikehendaki.

Berdasar analisis ini dapat dikemukakan bahwa konsep pendidikan moral universal dalam paradigm Islam adalah dalam kerangka mengembangkan kekhalifaan manusia yang mempunyai fungsi untuk menyelamatkan alam semesta dengan menghargai nilai-nilai kemanusiaan manusia.

\section{KESIMPULAN}

Islam berpandangan bahwa manusia adalah makhluk Tuhan yang mendapat legalitas atau tugas sebagai khalifah di bumi (khalifatu fi al-ardh) kekhalifaan manusia adalah amanah ketuhanan (khalifah dalam Islam memiliki nilai spiritual) dan penciptaan alam semesta ditujukan untuk kesejahtraan manusia, tugas manusia adalah memakmurkan alam semesta dalam kemasan "ibadah" Kepada Allah.

Konsep pendidikan moral universal dalam paradigma Islam adalah dalam rangka mengembangkan kkhalifahan manusia yang mempunyai fungsi untuk menyelamatkan alam semesta dengan menghargai nilai-nilai kemanusiaan manusia.

\section{REFERENSI}

Abdalati, Hammudah,1986, Islam Suatu Kepastian, Natinal Offset Printing Press, Riyadh.

Aly, Fachri dan Effendy Bahtiar,1986, Merambah Jalan Baru Islam, Mizan, Bandung.

Boisard, Marcel A. 1980, L'Humanisme DeL'Islam, alih bahasa M. Rasjidi, Bulan Bintang Jakarta.

Departemen Agama Republik Indonesia, 1986/1987, Al-Qur'an dan terjemahnya, YPP/Penafsir Al-Qur'an, Jakarta.
Hasan Muhammad Thalchah, 1988," Aspek Manusia dalam Upaya pelestarian Lingkungan", Aula Risalah Nadhatul Ulama Jawa Timur, No.3/Maret.

Isngadi, 1997, "Kearah pengertian Islam", Mimbar Pembangunan Agama, No.127/Syawal-Dzulqa'dah 1417 H/April.

Madjid, Nurcholish,1992, Islam Keindonesiaan dan Kemodernan, Mizan, Bandung.

Murtadho,1991, Pengantar Ilmu Hadits, IAIN Sunan Ampel, Tulung Agung.

Moeliono, Anton M., et.al,1989, Kamus Besar Bahasa Indonesia, Balai Pustaka, Jakarta.

Saifullah, Ali, 1983, Pendidikan Internasional and edult Education, Usaha Nasional, Surabaya.

Soetandyo Wignjosoebroto, 1994, Pendidikan Sebagai Usaha Pengembangan (sumber) Manusia Di Tengah-tengah Zaman Kemajuan Iptek Menjelang PJPT II, Makalah rujukan disajikan dalam rangka pembekalan para lulusan Fak. Tarbiyah Tulung Agung IAIN Sunan Ampel, Makalah tidak diterbitkan.

Syauki, Achmad,1993, Lintasan Sejarah AlQur'an, Sulita, Bandung.

Tatapangarsa, Humaidi,1982, Kuliah Aqidah Lengkap, Bina Ilmu, Surabaya.

Tim Penyusun Teks Book Dirasat Islamiyah,1993, Teks Book Dirasat Islamuyah Al-Quran, Al-Hadits, Fiqih dan Pranata social, CV. anika Bahagia Offiset, Surabaya.

Yafie, Ali,1989, "Menggagas Fiqih dan Pranata Sosial, dalam muntaha Azhari (Eds), Islam Indonesia Menatap Masa Depan, P3M, Jakarta. 